\title{
STUDY ON THE ACOUSTIC REFLEX IN BINAURAL HEARING BY MEANS OF THE IMPEDANCE METHOD
}

\author{
NAOSHI KODAMA, M. D. \\ Department of Otorhinolaryngology, Fukushima Medical College, Fukushima \\ (Director: J. Ouchi, M. D.)
}

The human acoustic reflex in binaural and monaural hearing were observed in free field by means of the impedance method to clarify the mechanisms of the intratympanic muscles.

The results were obtained as follows.

1) When the sound source was the front, the impedance-change was larger in binaural hearing than in monaural hearing. (Phenomenon I)

2) When the sound source was the side, the difference of the impedance-change between both ear was smaller in binaural hearing than in monaural hearing, furthermore the impedancechange was larger of ipsilateral ear of the sound source than of contralateral one everytime. (Phenomenon II)

3) It was deduced that both Phenomenon I and II obtained from this study were caused by that the binaural interaction generated in superior olivary complex had influence on the acoustic reflex with bilateral arc.

4) The meaning of Phenomenon I was that the binaural summation as result of binaural interaction was confirmed by observation on the acoustic reflex.

The meaning of Phenomenon II was that the intratympanic muscles which contracted as reflection of binaural interaction was able to transmit loud sound changing for attenuated one to each inner ear keeping the approximate value of sound pressure-difference between both ear.

In conclusion, it was suggested that the acoustic reflex not only protect inner ear from loud sound but also perticipate in the mechanisms of the directional hearing.

$$
\begin{aligned}
& \text { インピーダンス法による両耳聴時の音響 } \\
& \text { 性耳小骨筋反射に関する研究 }
\end{aligned}
$$

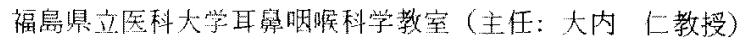$$
\text { 小王直 志 }
$$

\section{緒言}

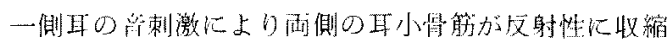
することを，1899年 Hammerschlag ${ }^{12}$ が鼓膜張筋につ

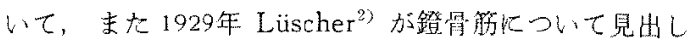

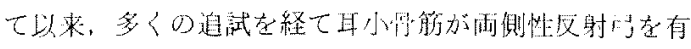

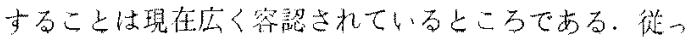

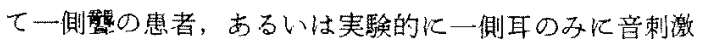
を与无九片耳聴の場合を除けば，两耳で学を聴取した場

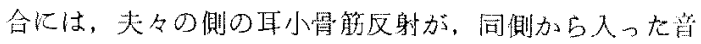
のみならず他側からの音です影怊を受けるだるうことは

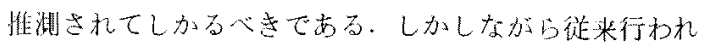

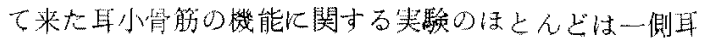




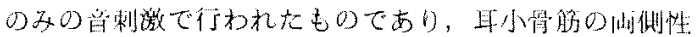

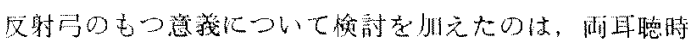

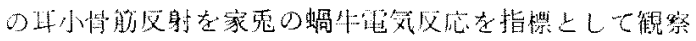
した教公の多且（1968）のみである。

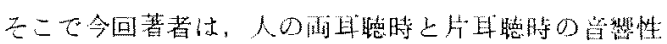
耳小骨筋又射をインピーダンス变化測定法で観残するこ とにより，雨耳で音を㯖取した場合反対耳からの等の影

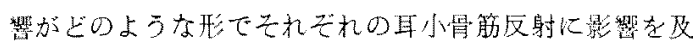

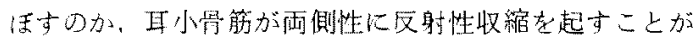

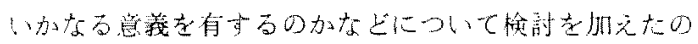
て卸告する次第である。

実 験 方 法

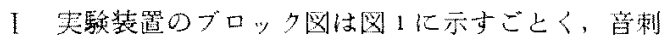
激采と記録系化分加机ている。

1) 学制激系

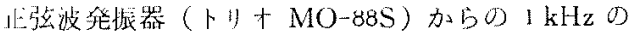
グナルを、減敖器（トリオ T-121-4D）, 㘿憎器(ト

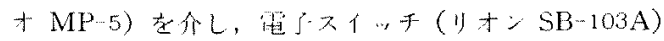

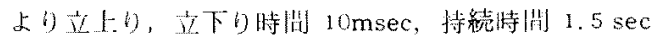

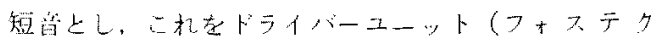
D 221）に導き，自由音場で発振させた。てててっ 女雨側外耳道儿大夕同規格のマイクロフォンを組込九 ある人の䫏部モデル（テクニクス RP-3280E，以下頭 モデルと敗す）てとらえ，2千ャネル增幅器（ソ二

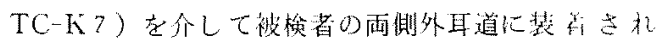

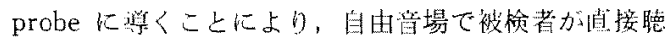

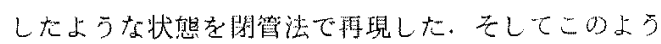

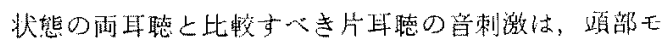
ルからの左右いずれかの出力を遮断して行った、この

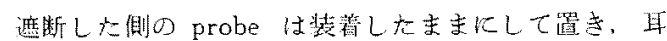
の役制学果たさせた。

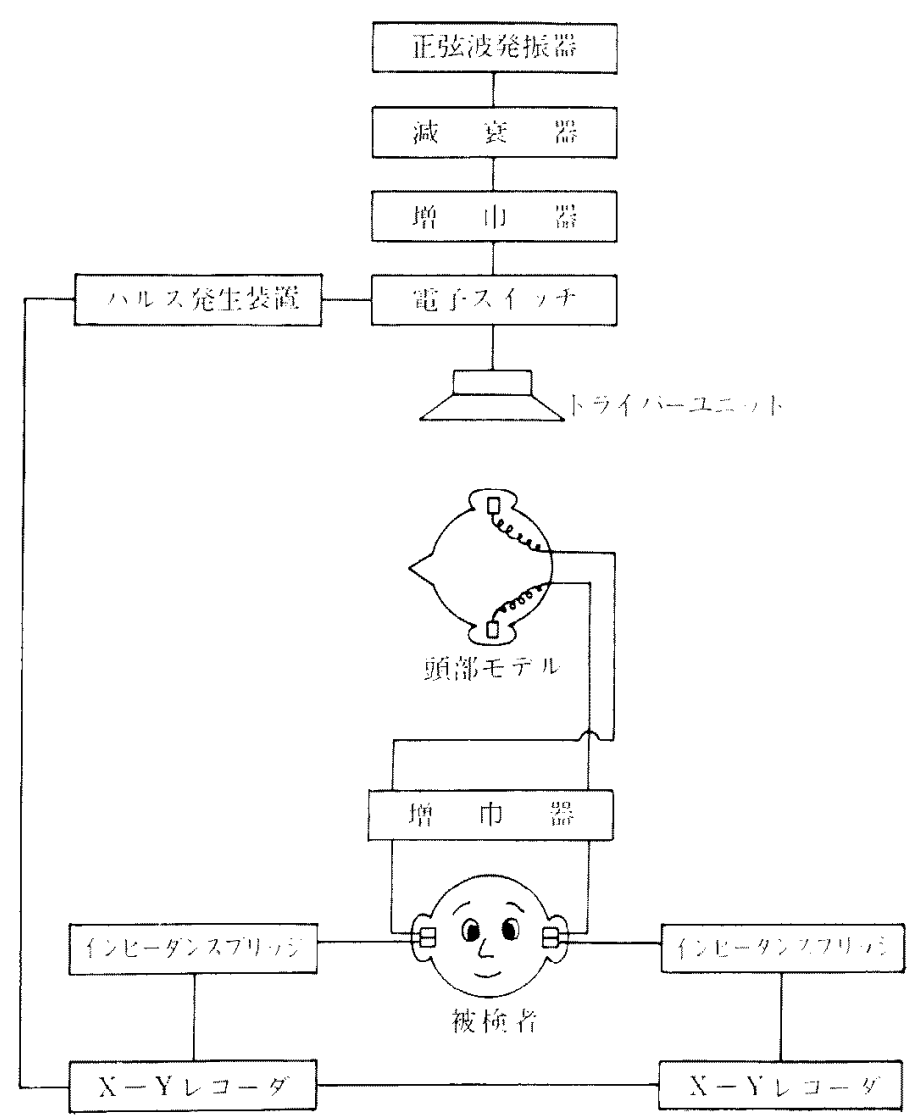

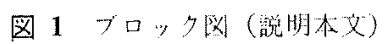


A
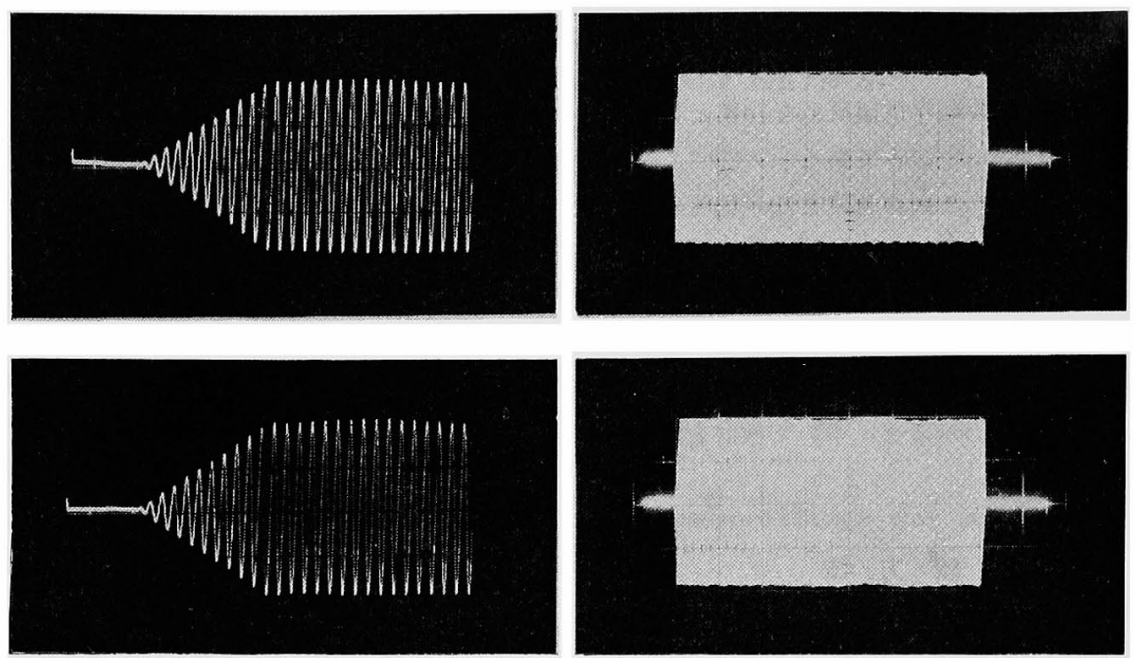

$20 \mathrm{msec}$

$1 \mathrm{sec}$

A 頭部モデルの右側外耳道の位置でとらえた音波形

B 頭部モデル及び增幅器を介して probe より発振された音波形

図 2 刺激音波形

左側の波形は立上りの部分，右側の波形は全体を示しているが， いずれも A と B にはほとんど差は認められない

図 2 は, 自由音場で音源から発振された音を，頭部モ デルの右側外耳道浪組込んであるマイクロフォンをはず し，鼓膜面に相当する位置にプローブチューブつノクロ フォンを置いてとらえた時の音波形と，頭部モデルおよ び增幅器を介して probe に導かれて発振された時の音 を，同じプローブチューブマイクロフォンでとらえた音 波形を示したものであるが，両者間にはほとんど相遣を 認めていない，また左側についても同様の方法で検討し てみたが，やはり右側と同様の結果が得られており，自 由音場での音刺激を閉管法で再現し得たことを示してい る.

\section{2）記 録 系}

音響性耳小骨筋反射の測定は， 2 台の acoustic impedance bridge (Madsen ZO-72) で同時に行い, これを 2 台の X-Y レコーダ (渡辺測器 WX 440)で記録した. この際 probe からの音刺激は外部からの出力で行われ ているため, Madsen ZO-72 に内蔵されているオージオ メータの出力は遮断した状態で行った。また探査音は $220 \mathrm{~Hz}$ とした.

以上の装置で実験を行うにあたり，音刺激装置こ記録
装置を連動させる目的で，2台の X-Yレコーダと電子 スイッチをパルス発生装置（日本光電 MSE-20)飞より 駆動し， X-Yレコーダのペンが動き始めてから 1 秒後 に音刺激が加わるようにした，また器械の操作音などが 頭部モデルを介して被検者の耳に入るのを防ぐため，音 源执よび頭部モデルと被検者拈よび測定器類は夫々異な る防音室に配置した。（図 3,4）

II 音刺激方法飞ついて

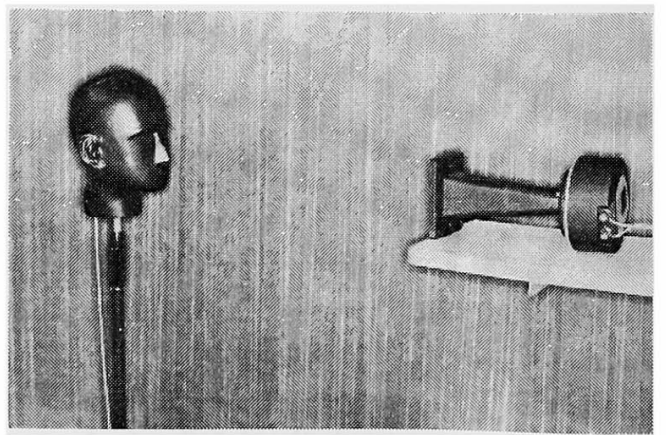

図 3 音刺激装置（自由音場における音源と 頭部モデル) 


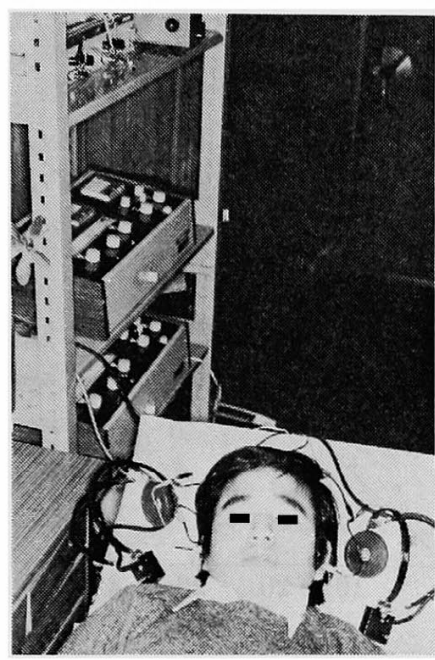

図 4 測 定装 置

音源と頭部モデルの向関係は，両耳に入る音の強 さ，位相打よび時間に全く差のない状態，すなわち音源 を頭部モデルの正面に置いた場合上, 両耳から入る音の 違いが最も大きくなるような状態，すなわち音源を頭部 モデルの真横に置いた場合の 2 つの方法をとり，夫々の 場合について両耳聴, 片耳聴の実験を行うこととし, 以 下の 5 つの組合せを設定した.（図 5 ）

すなわち，図 5 の(1)，(2)は，音源を頭部モデルの正面 飞置いた場合の両耳聴と片耳聴，(3)，(4)，(5)は，夫々音 源を頭部モデルの真横に置いた場合の両耳聴, 音源側耳 による片耳聴，そして音源と反対側耳による片耳聴であ 万.

また，音源から頭部モデルの頭頂部までの距離は $50 \mathrm{~cm}$ と $1 \mathrm{~m} の 2$ 種類とし, 夫々の距離について前述の(1) (5) の実験を行った. そして, その時飞被検者に与えられる 音圧は, 音源が正面の場合, 両耳共 $50 \mathrm{~cm}$ が 103dBSPL,

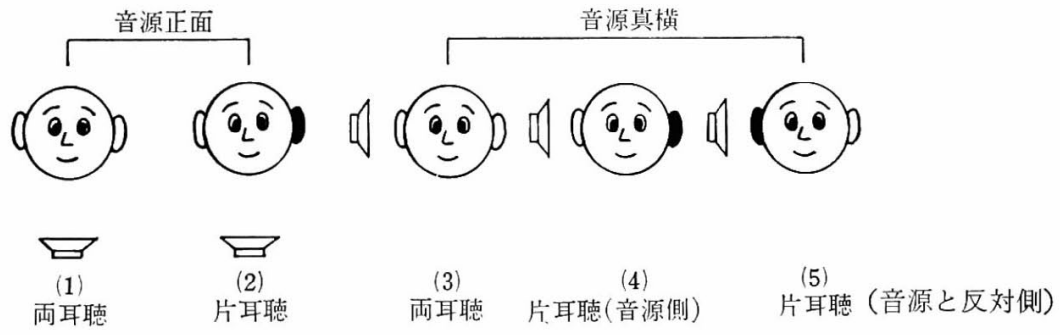

図 5 音源の方向と，その時の両耳聴と片耳聴の組合せ
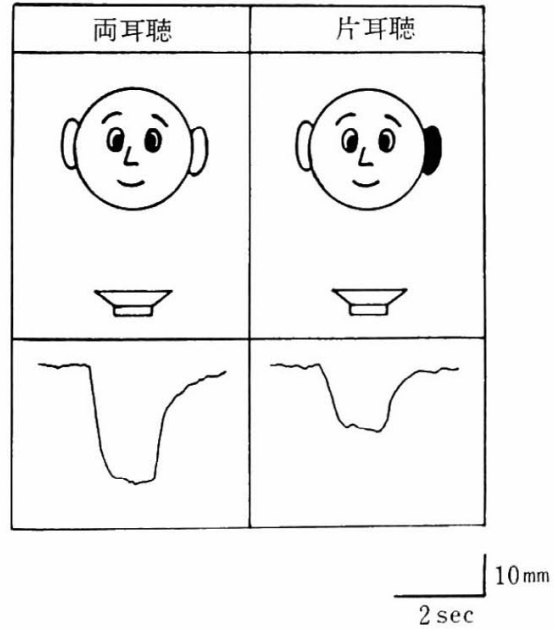

図 6 音源が正面 $50 \mathrm{~cm}$ の場合の両耳聴時と片 耳聴時の耳小骨筋反射波形
$1 \mathrm{~m}$ が $95 \mathrm{dBSPL}$, 音源が真横の場合, 音源側耳が夫々 $105 \mathrm{dBSPL}, 99 \mathrm{dBSPL} ＼mathrm{~ そ し て 音 源 と 反 対 側 耳 て ゙ は 夫 ~}$

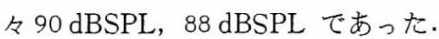

\section{III 実験対象}

両耳と屯聴力正常で, 耳疾患の既往歴がなく, かつ両 耳とも以下に述べる条件のすべてを満たす成人10名を実 験対象とした。

1）耳小骨筋反射域值が正常箅囲であること.

2) static compliance が正常篹囲であること.

3) reversed reflex の出現がないこと.

4) tympanogram がA型であること.

\section{実 験 成 績}

I 音源が正面の場合の両耳聴と片耳聴の比較

1）距離 $50 \mathrm{~cm}$ の場合

図 6 は，代表例 N.K.Kおける音源が正面 $50 \mathrm{~cm}$ の場 


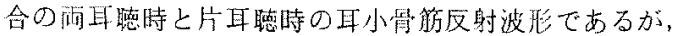

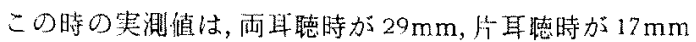
となり，雨耳聴時の方が片耳㯖時より季インピーダンス

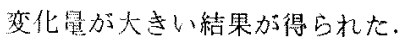

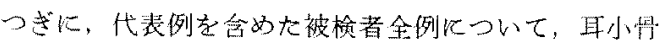

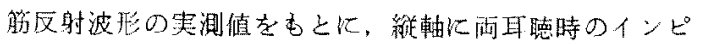
ーダンス变化䁷を，横軸に片耳聼時のそれをプロットし

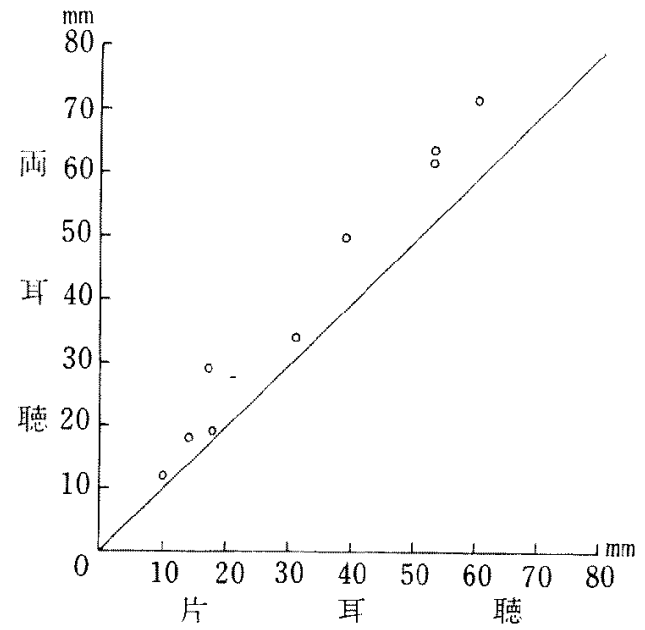

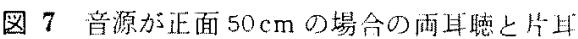
㙏の故较

被検者によりインピーダンス变化舅にバ ラツキはあるが，いず机の被检者も雨耳猢

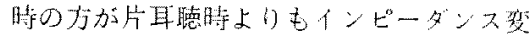
化翼が大きい
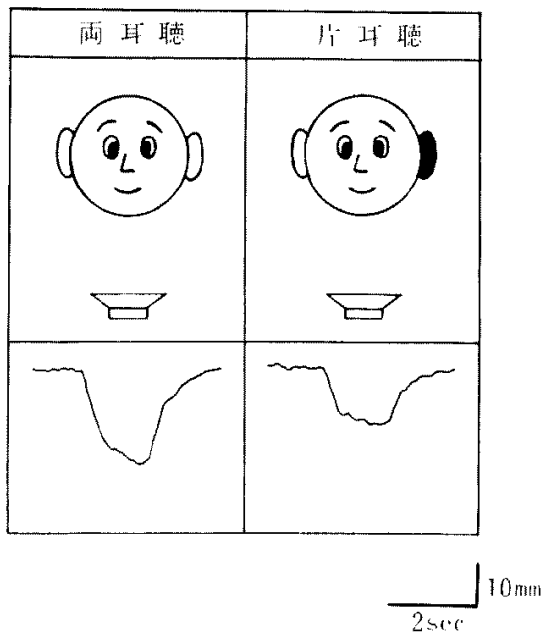

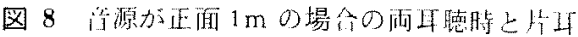

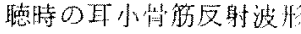

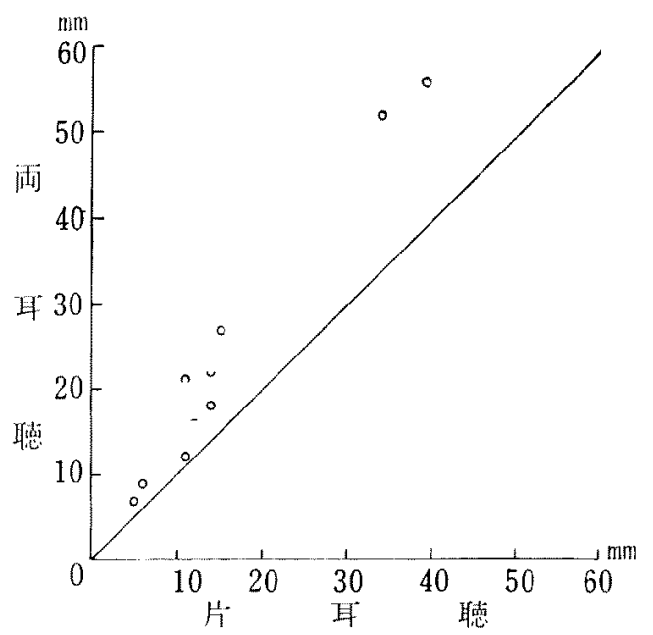

図 9 省源加正面 $1 \mathrm{~m}$ 場会の雨耳聴上片耳聴 0 比整

距離 $50 \mathrm{~cm}$ の場台と同様いずれの被榆者 も面耳㯖時の方が版耳聴時よりもインピー ダンス殏化墨が大きい

てみると圈てのごしくになる。

被検者により，雨耳㯖，片耳丞いずれもインビーダン

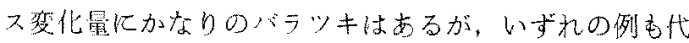
表例に見られたごとく，两耳聴時の方加版耳嗃時上りも インピーダンス変化锂が大きいにとがかかった。

2) 距離 $1 \mathrm{~m}$ 場畣

图8は，同じ代表例に和ける古源が正面 $1 \mathrm{~m}$ 場台の

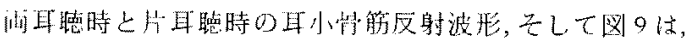
代表例老含めた被检者全例についての四耳㯖時上片耳德 時のインピーダンス寉化量を，距睢 $50 \mathrm{~cm}$ の場合上同様 の方法で比僌して見たものである。

やはり被检者により，雨耳㯖，片耳㯖いずれもインピ 一ダンス变化量にバラッキはあるものの，全例に共通し て距離 $50 \mathrm{~cm}$ の場合と同样，仙斗㯖時の方が片耳㯖時上 りもインピーダンス变化量が大きい結果が得られた。

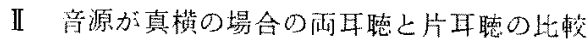

1) 距瞅 $50 \mathrm{~cm}$ の場合

冈10は，同じ代表例にォける古源が基横 $50 \mathrm{~cm}$ の䭪合

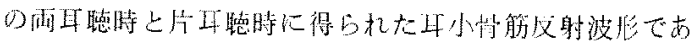

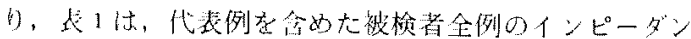

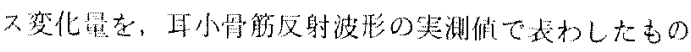
でる。

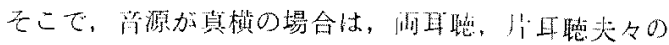

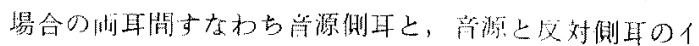




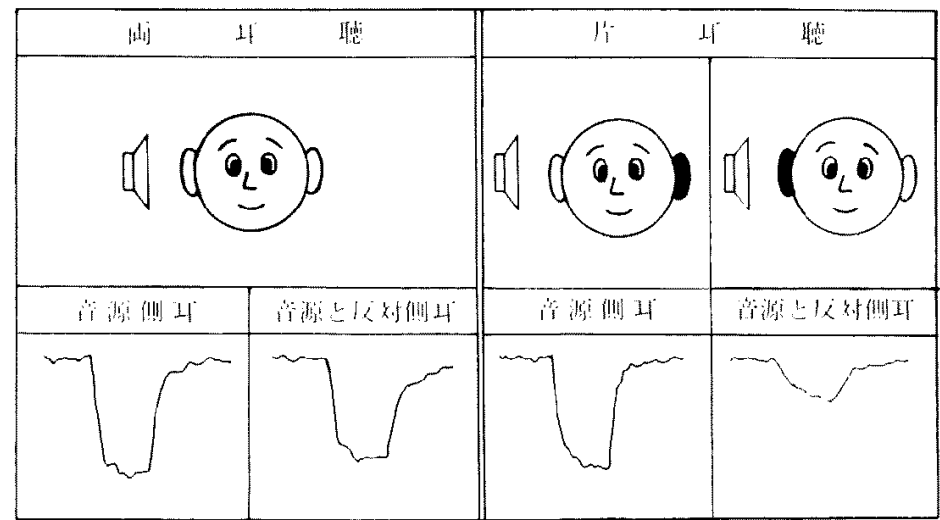

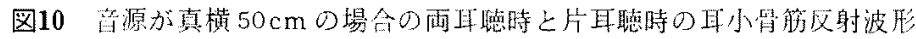

表 1 音源が真横 $50 \mathrm{~cm}$ の場合の雨耳㯖時と片耳㯖時のインビーダンス变化量（恝澌值）

\begin{tabular}{|c|c|c|c|c|c|c|c|c|c|c|c|}
\hline 测定耳 & 被検者 & $\mathrm{N} . \mathrm{K}$ & M. $\mathrm{H}$ & $\mathrm{T}$ & M. S & Y. S & K. K & Y. O & S. $\mathrm{O}$ & I. $\mathrm{M}$ & $\mathrm{Y} . \mathrm{K}$ \\
\hline \multirow{2}{*}{ 阔早聴 } & 煚源側耳 & 28 & 30 & 10 & 20 & 30 & 17 & 68 & 65 & 50 & 55 \\
\hline & 音源と反対側旦 & 26 & 23 & 9 & 14 & 23 & 15 & 56 & 64 & 41 & 38 \\
\hline \multirow{2}{*}{ 片 且 } & 筒源㓱且 & 25 & 38 & 9 & 10 & 34 & 12 & 63 & 62 & 45 & 57 \\
\hline & 苩源と反斉側耳 & 10 & 6 & 4 & 6 & 15 & 4 & 26 & 23 & 6 & 6 \\
\hline
\end{tabular}

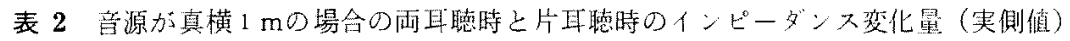

\begin{tabular}{|c|c|c|c|c|c|c|c|c|c|c|c|}
\hline 湘定耳 & 被検者 & N. K & M. H & T. T & M. & Y. S & K. K & Y. O & S. O & I. $\mathrm{M}$ & $\mathrm{Y} . \mathrm{K}$ \\
\hline \multirow{2}{*}{ 们正 聏 } & 源側 耳 & 20 & 22 & 8 & a & 18 & 11 & 57 & $5 ?$ & 23 & 26 \\
\hline & 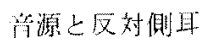 & 18 & 12 & 7 & 8 & 15 & 10 & 53 & 54 & 20 & 22 \\
\hline \multirow{2}{*}{ 片且垒 } & 音源側 & 19 & 29 & 7 & 7 & 22 & 5 & 51 & 54 & 22 & 34 \\
\hline & 竍源亡反对側耳 & 6 & 3 & 3 & 4 & 8 & 3 & 21 & 8 & 5 & 3 \\
\hline
\end{tabular}

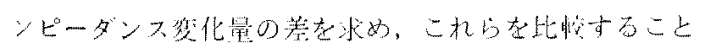

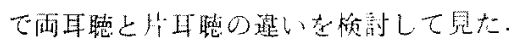

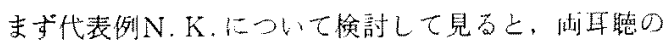

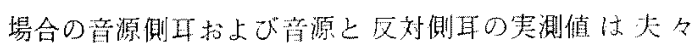

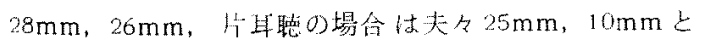

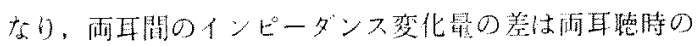

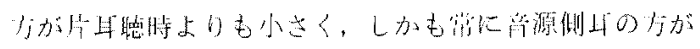

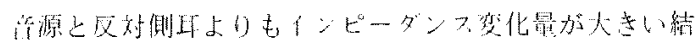

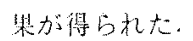

次に表1本もとに，代表例を含め大被㛟者主例につい

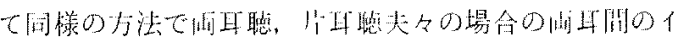

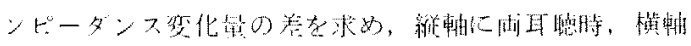


に片耳㯖時の徂をプロットして見たのが図11である。

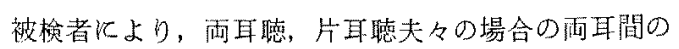
インピーダンス穽化国の盖にバラツキはあるものの, 代 表例火見られた現家が全例に共通して諗められた。

2) 距䧺 $1 \mathrm{~m}$ 湯台

図12は，同一代表洌飞おける音源が其横 $1 \mathrm{~m}$ 場合の

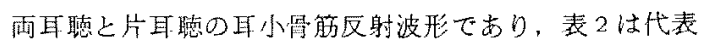
例を会めた被俟者全例儿ついて得られたインピーダンス 変化量を夷測值で表わしたものである。

そこで，距雄 $50 \mathrm{~cm}$ の場合と同様の方法て両耳恥と片 耳㯖の比校をして見ると四13のごとくになる。

やはり被検者に上り雨耳聼，片耳聴夫々の場合の雨耳 間のインピーダンス变化墨の差にバラッキはあるもの $の$, 全例炕共通して距雕 $50 \mathrm{~cm}$ の場合と同橡，耐耳間の インピーダンス变化量の差は，雨耳㯖時の力が片耳聴時

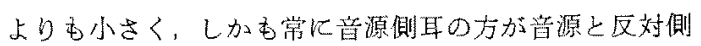
耳よりもインピーダンス変化量が大きいといら結果が得 btat.

\section{考按}

I 実唭方法について

菖烟性耳小骨筋反射については，1878年 Hensen 大の教膜張筋で観察して以来，各種動物，人を対象とし て多くの研究が行われて来た.これらの研究で行われた 音望性耳小骨筋反射の観祭法としては, 直視法, 光学的 湘定法, 筋電图学的测定法, 外耳道年測定法, 艄牛電気 反応測定法，インピーダンス变化湘定法などがあるが，

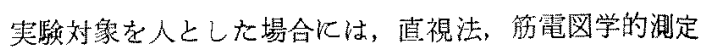
法なとのように外科的操作を加兄て直接観祭寸るのは团 難なため, 外耳道生測定法, インピーダンス湾化測定法

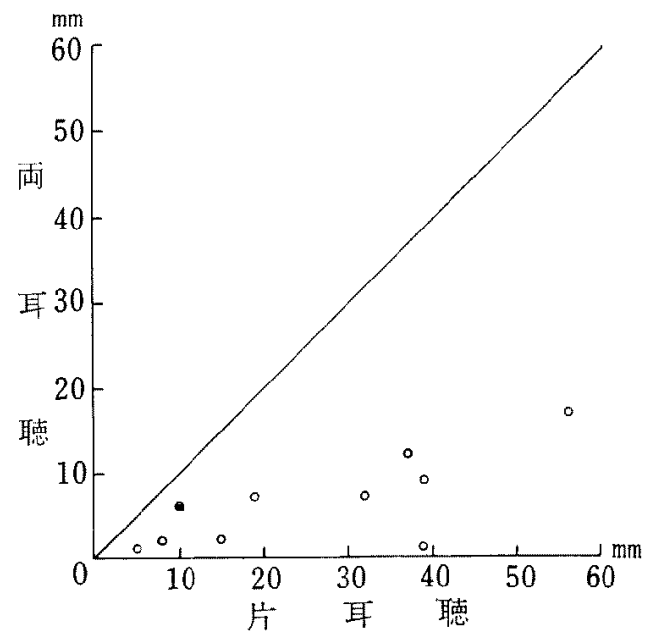

縦軸：両耳聴時の点源側耳と、音源と反対 側耳のインピーダンス変化量の差

横軸：片耳聴時の音源側耳と、音源と反对 侧耳のインピーダンス变化量の差

图11筸源が真横 $50 \mathrm{~cm}$ の場合の両耳㯖と片耳 聴の比較

被检者により，両耳聴，片耳聴いずれも その值にバラッキはあるが，全例両耳聴時 の方が片耳鳃時上りを両其間のインピーダ ンス变化量の差が小さい
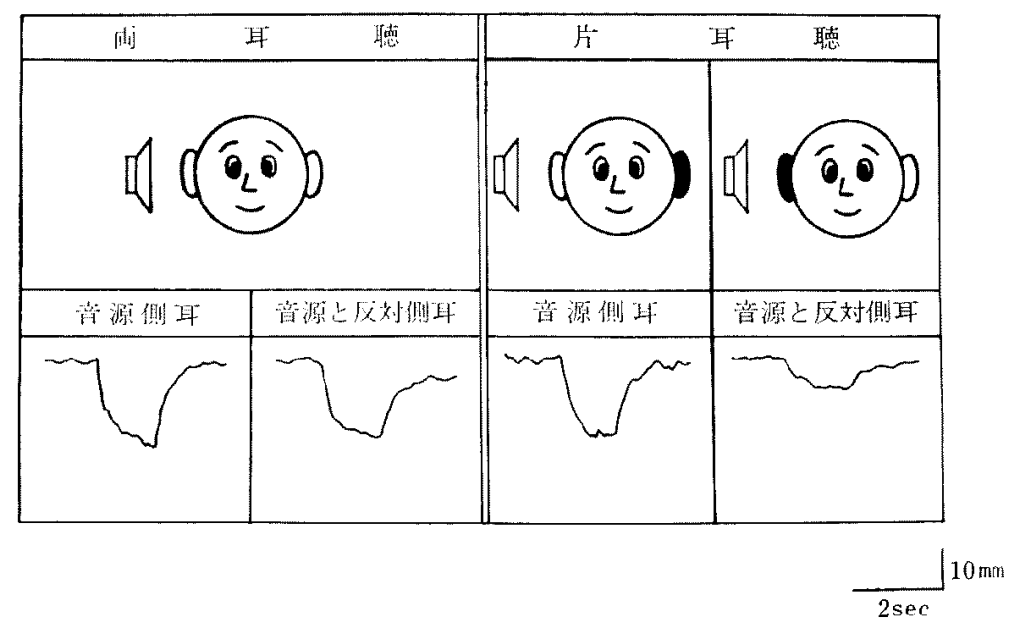

図12 音源が真横 $1 \mathrm{~m}$ の場合の両耳聴時と片耳㯖時の耳小骨筋反射波形 


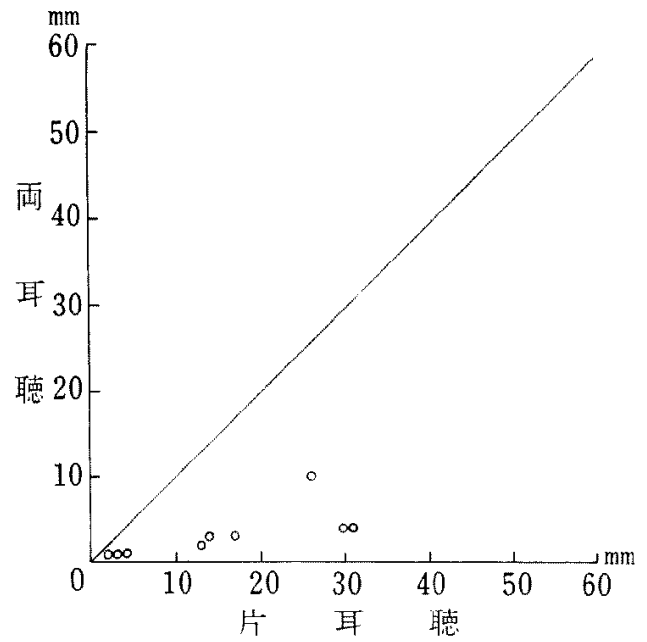

縦軸：両耳聴時の音源側耳と、音源と反对 側耳のインピーダンス変化星の差

横軸：片耳聴時の音源側耳と、音源と反对 側耳のインピーダンス变化量の差

図13 音源が真横 $1 \mathrm{~m}$ の場合の雨耳聴上片耳㯖 の比較

距離 $50 \mathrm{~cm}$ の場合と同様，いず和の被梌 者も両耳德時の方が片耳聴時より李雨耳問 のインピーダンス变化童の差が小さい

などの間接的な方法が用いられている。

このうち, 今回著者が用いたインピーダンス㤎化測定 法は, $\operatorname{Metz}(1951)^{5)}, \operatorname{Jepsen}(1951)^{6)}, \operatorname{M\phi ller}(1958)^{3)}$, Terkildsen et al(1960) ${ }^{87}$, Zwislocki (1961) ${ }^{97}$ 等の基整 的研究を経て夷用化され, 今やルーチンの臨床検查法上 して広く利用されつつ古るが，伴来の装置は測定耳と反 対側加音刺潡を与文万仕組み（いわ㠴る contralateral stimulation)であった為，著者のごとく测定耳加らの音 刺激をも必要上する耐耳聴時の耳小骬筋反射の観察は不 可能であった。しかし最近化なり測定耳加ら口音刺激 (いわ化る ipsilateral stimulation) も行无るように改 良された装置が軽品化されたので，今回の実䮖はこのタ イプである Madsen ZO-72を用いて行った訳である。

この acoustic impedance bridge Madsen 2O-72 $\mathrm{k}$, この装置の湘定原理上，耳小骨筇反射の大きさを䋓対的 な物理量としてとら总ることは出来ないが，XーY レコ

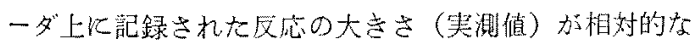
量としてのインピーダンス变化量の意味を持つようにな っている，そこで，今回の実貭では，実際てX-Yレコ 一ダ上記記録された反射波形の実測值をインピーダンス
变化最として检馀死行い, acoustic impedance bridge $\varnothing$

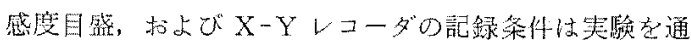
して商に一定の值に固定して行った。

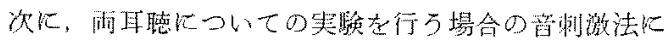
ついてであるが，大别すると free field method と earphone method があり，生理的な状热での雨目揌の観察 の場合は free field method が, 陑耳から入る音の時間 差之音王差を分微して音呈示して音方向感成立機序の解 析などを目的とする場合には earphone method が適し ている。

今回著者が目的としたのは生理的な状態での闻耳㯖の

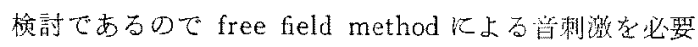
とした訳であるが，インピーダンス变化測定法で音䪪性 耳小骨筋反射を観察する為には外耳道を probe で密閣 することになり，free field method に上る奏䮖加行光

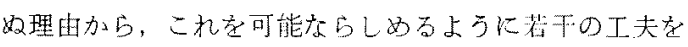
行った.

すなわち，自由音場で与兄的た刺激音を人頭大の碩 部モデルの雨側外耳道に組込んである2つのマイクロフ オンでとら光，2チャ亦儿增輻器を介して被㭘者の雨側 外耳道儿装着された probe に臫くことにより，自由音

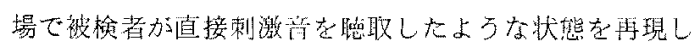
た訳である。

このように，自由音場で与充られた音老2つのマイク ロフォンを組込九だ頍部モデルを介してイヤフォンで与 总る方法法, 久保田 $(1957)^{1111}$, 服部ら (1969) ${ }^{11}$ が音

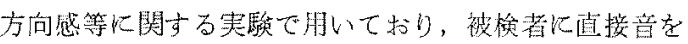
与えるのはイヤフォンで古が，内容的には前述の earphone method とは異なり, 光しる free field method というべきである。著者は，顔部モデルには被检者の外 耳道化装着された probe の先端の位置とほほ等しい部 位に小型のマイクロフォンが組込まれている精展の高い

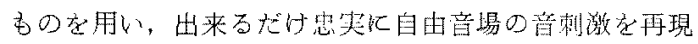
するょう心掛け大。

II 今回の実䮖で認めbれた現象の成立機けについて

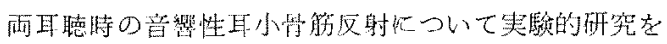
行った多田 ${ }^{3}$ は，耳小胃節の生理的機能已乙て徉来最毛

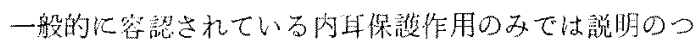
加ない現象在見出し，この現象は，従来行わ机て来た一

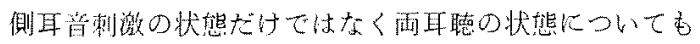
桧討することではじあて見出し得るものであるとし，耳

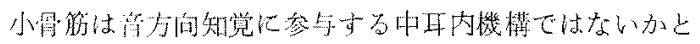

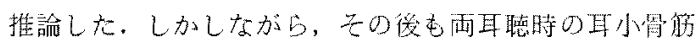


反射についての報告は見当らず，この教え加一般的に管 琶されているとは罟し䨅い。

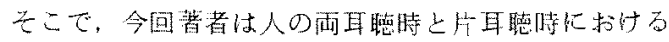

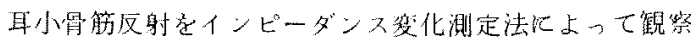

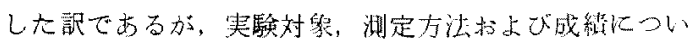
ての表現力法は異なるものの，多四加見出したもの上ほ ほ同榉の現象を被検者全例に其通して留めるこ上が出来 t.

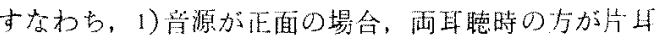
㯖時よりもインピーダンス変化量が大きいこと(以下現

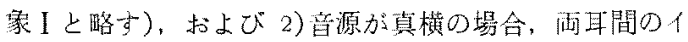

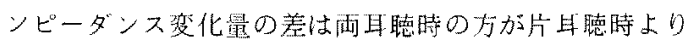
も小さく，しかも常に音源側耳の方加管源上反対側耳上 りもインピーダンス变化量が大きいこと（以下現象 II 略す） ○2つの現象である。

そこで，この2つの現整の成细機について少しく考 察してみたい。

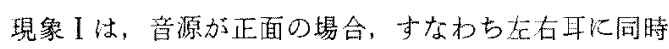
几同一音加人った場合の雨耳㯖と，この時に一側耳の刺 激音を遮断した片耳聴の場合のインピーダンス变化舅を 比較した時に見られた現象であり，現象Iは，音源が真

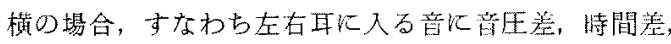

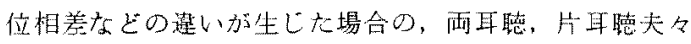
の実駼条件下に叔る雨耳間のインピーダンス变化冝の 差を比較した時に見られた現象である。

このように，現象Ｉ，Iは，夫々音刺激条件が界なる

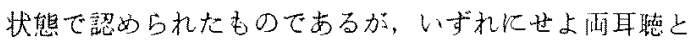

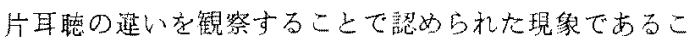

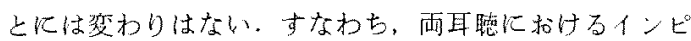
一ダンス变化輻とは，測定耳のみならず反対側耳にも何 らかの省刺激が与えられた状態て德られたるのであるの

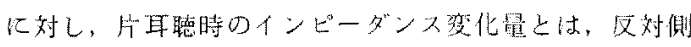
耳去らの音刺激がなく溂定耳のみの韋刺激で得られたも のであるといることである。侹って、これらの画耳德て 見られた現象は，一に反对側耳の音刺激の影勘が，耳小

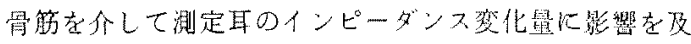
㭱したために起って来大もの上若えられる。

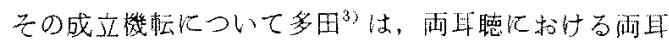

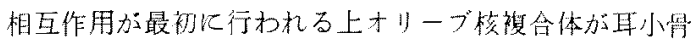
筋の反射引内にあることより，ここで行われた闻耳相百

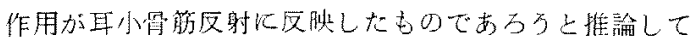
いる.

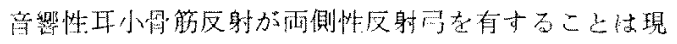

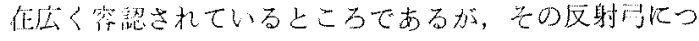
W七 Hammerschlag (1899) ${ }^{12}$. Moller (1961) ${ }^{13)}$, Keidel $(1960)^{11}$ bは一致して次のごとく述へている.

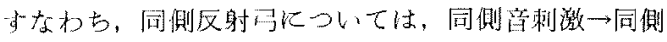

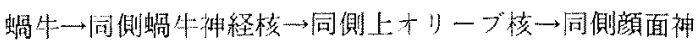

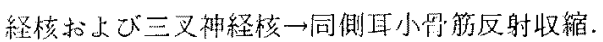

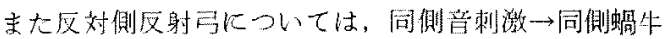

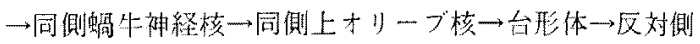

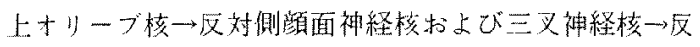
対側耳小骨筇反射収維，のごとくである。

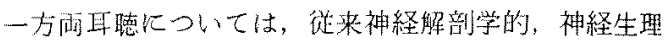

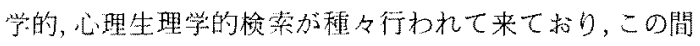
にあって婹筧求心路の交叉性, 非交叉性線維加最初に会 合するのは上小リーブ核襍合体，特にその中の副核であ

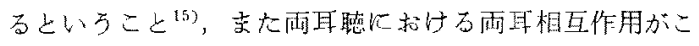

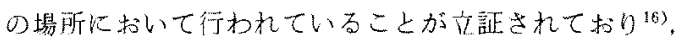

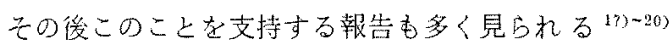
与なわち，上才りーブ核付近はその微妙な生理作用に上

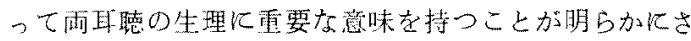
れている。しかもこの部位は耳小胃筋反射可の経路内て

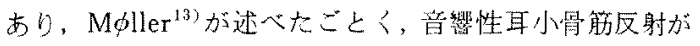
この部位の nervous activity を反㛗した状態で出現す るとすれば，雨耳聴時に，この部に起る雨耳相互作用が

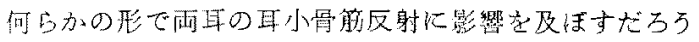
ことは推論しらるであるう。

したがって，今回想められた現泉IIII成文機枟に 関与する場として上ホリーブ核们近女想定寸るこ上が適 当であるらと考完る。

III今回の実駰で認められた現悡の意義について

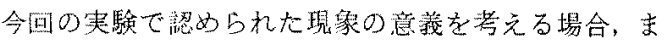
ず徉来言われている耳小骨脇の生理作用について惹える 必要があるう。

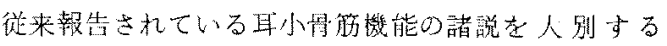
$\llcorner$, intensity control theory, frequency selection theory, labyrinthine pressure theory, fixation theory の4つに分けら机るが,こ机 control theory が一般的に密㒛さ扎ている.そして, この説には本来后音効果增強作用も㑒まれているのであ

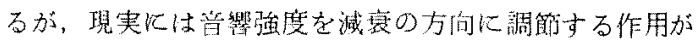
重視され，内耳老强大音加口保誰する上いう，以わ略る

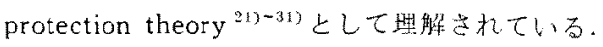

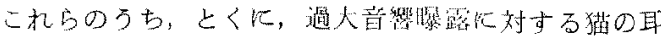

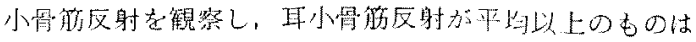




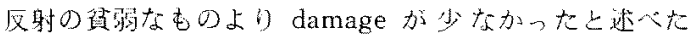

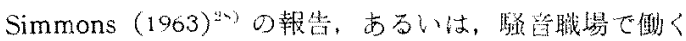

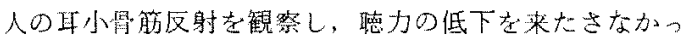

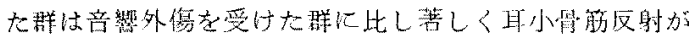

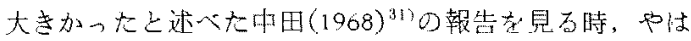

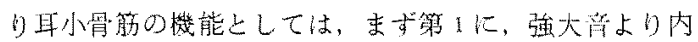

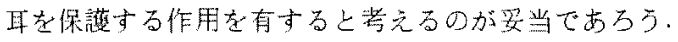

しかしながらこのような考元は，今国の著者の片耳嗃

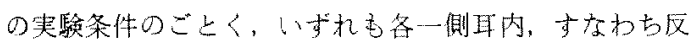

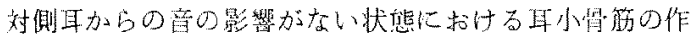
用在㛟討して得られたものであり，今回の著者の而耳聼

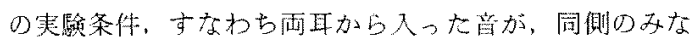

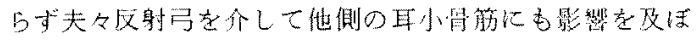

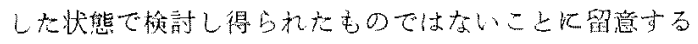
我要がある。

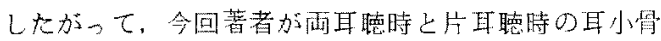
筋反射の嚾いなインヒーダンス夜化測定法で覞察するこ

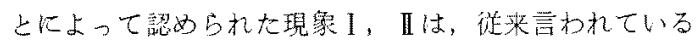

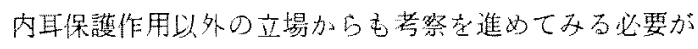
あると考之る。

1) 現聚 $1 k D に$

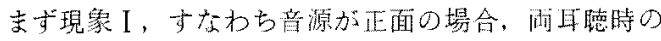

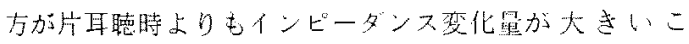
と、についてであるが、このことは而耳に，同時に同一 高が入った力片片加ら入った場合よりもインピーダン

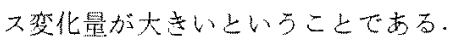

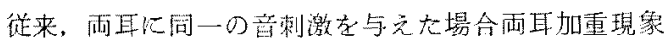
が生しるということが種々の心理生理学的, 電気生理学 的顺索で確認されており，その報告も多く見られる

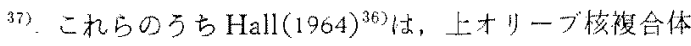
の副核ニューロンて雨耳加重現象の存在を哂的ている。

したがって，耐耳相互作用が最初に行わ和る上才り一

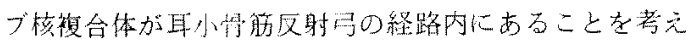
れば，現整 Iは，雨丰相互作用の結果生した间耳加電現 彖が耳小骨筋反射に反映したこよにより㒛められたもの ですると推祭することが雀来よう。

2) 現整政ついて

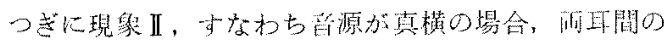

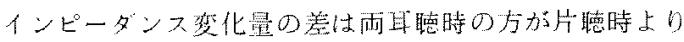

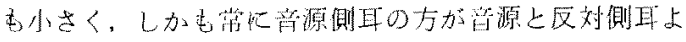
りむインピーダンス茨化量が大きいこと，がいかなる急 俄を持ののかといることについて考嗉してみたい。

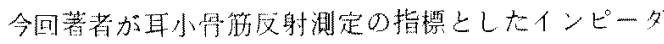

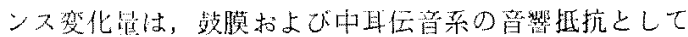

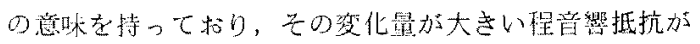
太きいことを西している。したがって，鼓膜に到暹した

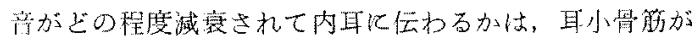
反射収縮老起した時のインピーダンス变化舅に左右され ることになる。

そこでこのような見地より現象を考察するなら

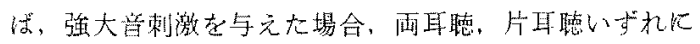

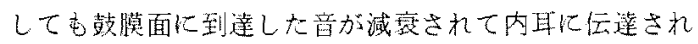
ることに变わりはないが，雨耳間のインピーダンス変化 昷の差が小さい状態であ台雨耳埴は，その差が大きい片

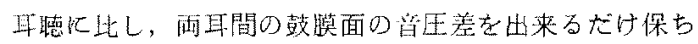
ながら内耳に位えるといる点に関しては朋らかに有利で

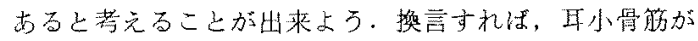
収縮することによって減意されて内耳儿到達した時の両

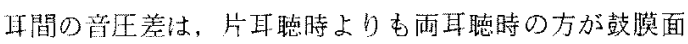
の音在差により近くなるということである。

ただ今回著者が行ったインピーダンス变化湘定法で

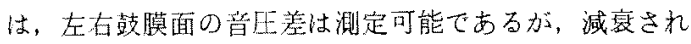
て内耳に到達した時の点在差は睍定不可能であり，その 差が実際どの程度なのかということについては言及出来

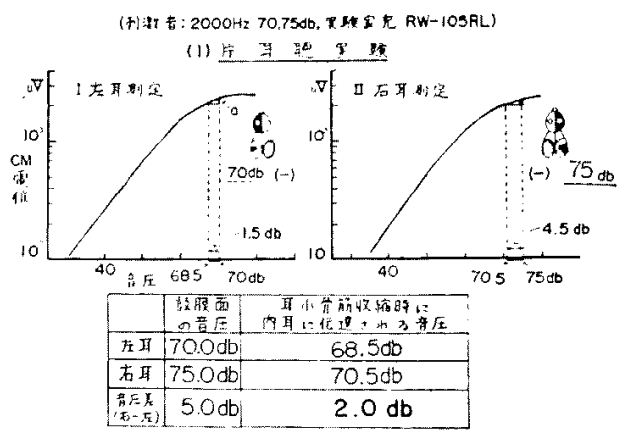

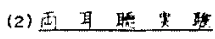

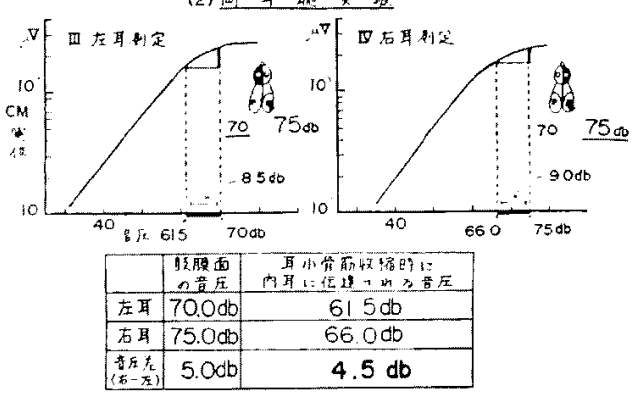

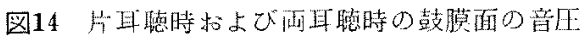

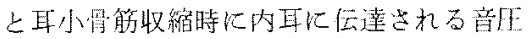
上の比䍗（多田による） 
ないそこで，このことを家费について，蛤牛電気反応

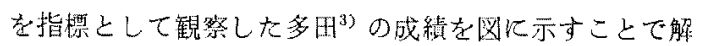
明してみたい。

これによると，左右の鼓脱面の音生差加 $5 \mathrm{~dB} の$ 場合， 减衰さ礼て内耳に到達した時の息压差は片耳璃で2.0

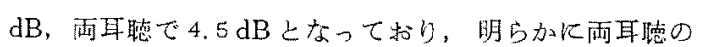
方が夫々の鼓膜面をうった音を，鼓膜面の音压差により 近い状態で内耳に伝達しているといら結果唯得られてい，

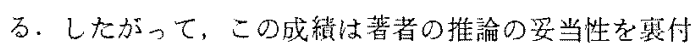
けるあのと解秋することが出来よう。

そこで，以上述べて来た現鼠川についての㛟討結果を まとめると次のごとくである.

雨耳で音を聴く際に，する意王差を持って左右の鼓膜 面に到達した音が夫々隇衰されて内耳飞伝えられる場

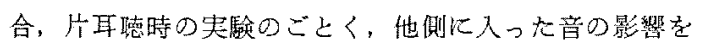
受けないで耳小祭筋が收面するのであれば，その音生差 は鼓膜面到達時の音压差よりも加なり小くなる。しか しながら，より生理的な状態である两耳聴では，耳小骨 筋が雨眰性反射弓を有するが故に，同側のみならす他側

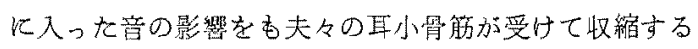
ことにより, 左右耳に入った暗加, 鼓膜面の盖压差飞近 い值学保ったまま内耳に位達されると考えることが出来 万。

然らばこのように考えた耳小学筋の僛き日常生活の 中でいかなる意味を持つのてあるろか。

このことを考えるにあたり、今回の現象が雨耳聴につ いて検討した結果得られたものであることに再度注目す る必要加する。

すなわち，雨耳聴の機能としては，㫮の方向感，雨耳 加重効果, 両耳分離能, 雨耳合成能などがあるが38，中

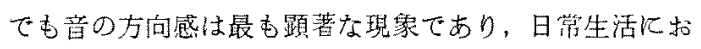
いても重要な役割を果たしている ${ }^{303}$ ，ということてあ り，また雨耳㯖時の耳小冒筋反射儿影背を及ほすだろう と推定した上オリーブ核被合体が音方向知觉に大きく関 与している ${ }^{16 / 173203367397}$ といろことでる。

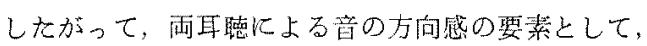

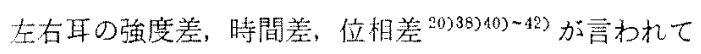
いることを考える時，强大音を雨耳で聴取した場合，左 右耳の耳小具筇加，同側のみならず反対側耳からの羙て

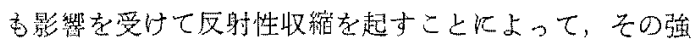

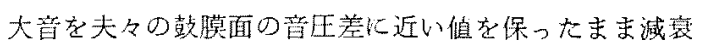
して内耳に伝えることが出来るという踷者の㛟行結果 は、内耳它保護す石上同時に, 音方向感の要素のエつて
ある强度差にも閏連を有しているのではないかと考える のはあながち製理なことではないでするう。

さbに, 耳小筋が位相むよび強度の瀻細な㒛整を行

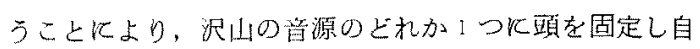
分の注急を向けることを可能にしているのではないかと $L た$ Lawrence (1965) 13) $D$ "rotation of attention theory”もあることを考えれば，反身性の器官として聴

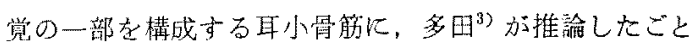
人，内耳保護作用以外にも㯖賞の本質的作用である音方 向知觉に関与する働さがあることも学えてよい上思われ 万。

\section{棇括並ひに結語}

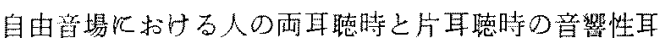
小胃筋区射の態度をインピーダンス离化測定法を指標上 して覞祭し，次のごとき結果を得た。

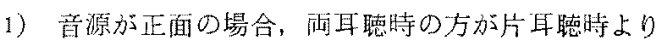
もインピーダンス变化量が大きいこと(すなわち現象 I) を認めた。

2）音源方顛横の場合，雨耳間のインピーダンス变化

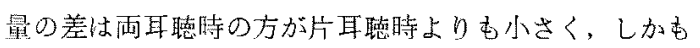
常隹源側耳の方が音源上反刘側耳よりbインピーダン ス変化置が大きいこと（すなわり現象II）を悡めた。

3）今回の丰験に蛇いて見出された現象I，II，い ずれも上オリーブ核付近で生した両耳相互作用が両側性 成射弓を有する耳小骨筋反射に影響を及ほした結果起。 た专の上推論した。

4）今回の实験に招いて見出された現象Ｉの意義は, 両耳相互作用の結果生じた雨耳加現象が耳小冎筇反射を 観祭することで確認さ机たことにあると考无た。

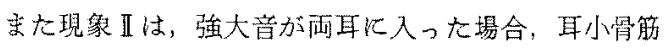
が闻耳相互作用を反眣した状態で反射性に収縮すること によって，その強大音を夫々の鼓膜面の岳王差に近い值 を保ったま来隇衰して内耳に任達することが出来るとい う点にあると考えた。このことから，音響性耳小骨笳反 身は，强大音恥取時に，内耳を保護すると同時に音方向 知觉にも関与するものでらるうと推墖した。

\section{参芳 献}

1) Hammerschlag $V:$ Ueber den Tensorreflex. Ohrenh. 46; 1-13, 1899.

2) Lüscher $E$ : Die Funktion des Musculus stapedius beim Menschen. Ztschr Hals-Nasen-u. Ohrenh. $23 ; 105-132,1929$. 


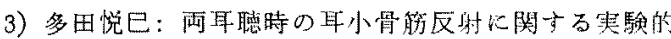
研笑。目率 71:729-750，1968。

4) Hensen $V$ : Beobachtungen Über die Tätigkeit des Trommelfellspanners bei Hund und Katze. Arch f Anat Physiol 2: 312-319, 1878.

5) Metz $O:$ Studies on the contraction of the tympanic muscles as indicated by changes in the impedance of the ear. Acta Otolaryng 39: 397$405,1951$.

6) Jepsen $O:$ The threshold of the reflexes of the intratympanjc muscles in normal material examined by means of the impedance method. Acta Oto-laryng 39: 406-408, 1951.

7) M $\phi$ ller $A R$ : Intra-aural muscle contraction in man, examined by measuring acoustic impedance of the ear. Laryngoscope 68: 48-62, 1958.

8) Terkildsen $K$ et al: An electroacoustic impedance measuring bridge for clinical use. Arch Otolaryng 72: 339-346, 1960.

9) Zwislocki $J$ : Acoustic measurement of the middle ear function. Ann Otol Rhinol Laryngol 70: 599-606, 1961 .

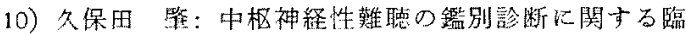
床的考察。日耳䑁 69:1953-1980，1957。

11）服部浩他：耳科㜔床朋陮易方向感テス卜浩。耳 舜臨床 $62: 89-95,1969$.

12) Hammerschlag $V$ : Ueber die Reflexbewegung des Musculus tensor tympani und ihre zentralen Bahnen. Arch f Ohrenh. 47: 251-275, 1899.

13) Móller $A R$ : Bilateral contraction of the tympanic muscles in man. Ann Otol Rhinol Laryngol 70 : 735-752, 1961.

14) Keidel W $D$ : Anatomie und Electrophysiologie der zentralen akustischen Bahnen. Hals-NasenOhren-Heilkunde, Band 3 Teil 3: 2013-2019, 1966.

15) Stotler $W A$ : An experimental study of the cells and connections of the superior olivary complex of the cat. Comp Neurol, 98: 401-423, 1953.

16) Galambos $R$ et al: Microelectrode study of superior olivary nuclei. Amer J Physiol 197: $527-536,1959$
17) Von Bergeijk $W A$ : Variation on a theme of Bébésy: A model of binaural interaction. J Acoust Soc Am 34: 1431-1437, 1962.

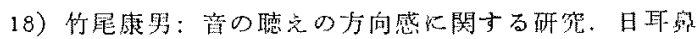
$67: 1272-1283,1964$

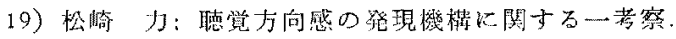
耳是 9: 467-470，1966。

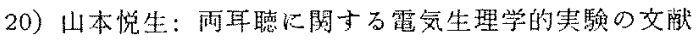

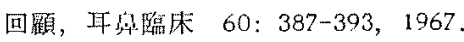

21) Wiggers $H C$ : The function of the intraaural muscles. Amer J Physiol 120: 771-780, 1937.

22) Weber $E G$ et al: The effect of the tympanic muscles upon sound transmission. Acta Otolaryng 45: 433-439, 1955.

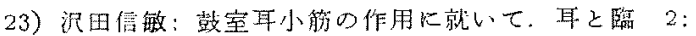
196-199, 1955.

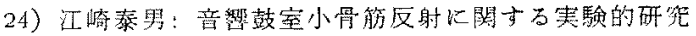
耳之隍 4: 24-48, 1958 .

25) Simmons FB: Middle ear muscle protection from the acoustic trauma of loud continuous sound. Ann Otol Rhin Laryngol 69: 1063-1071, 1960.

26）河由藤治: 耳小骨筋の鼓膜及び耳小骨理鎮に及ぼす

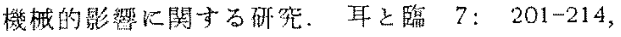
1961.

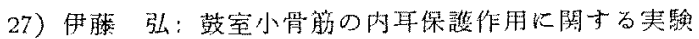
的研究。日下粤 60：1085-1095，1957。

28) Simmons $F B$ : Individual sound damage susceptibility. Ann Otol Rhin Laryngol 72: 528$547,1963$.

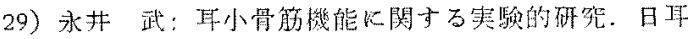
丘 71: 500-534, 1968.

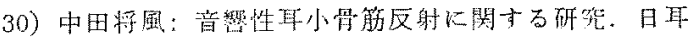
尛 71: 1658-1669, 1968.

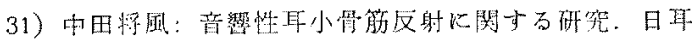
71: 1670-1683, 1968.

32) Reynolds $G S$ et al: Binaural summation of loudness. J Acoust Soc Am 32: 1337-1344, 1960.

33) Marks $L E$ : Binaural summation of the loudness of puretones. J Acoust Soc Am 64: 107113,1928 .

34) Dermody $P$ et al: Loudness summation with binaural hearing aids. Scand Audiol 4: 23-28, 1975. 
35) Blegrad B: Binaural summation of surfacerecorded electrocochleographic responses. Scand Audiol 4: 233-238, 1975.

36) Hall $J$ L: Binaural interaction in the accessory superior olivary nucleus of the cat. Cambridge, Mass. Massachusetts Institute of Technology,

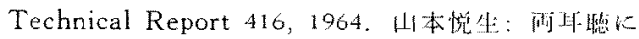

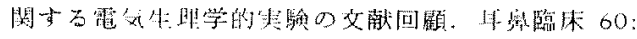
$387-393,1967$ 上b利用.

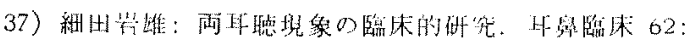
$1007-1029,1969$.

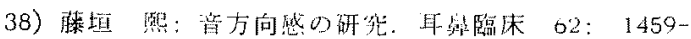
$1483,1969$.

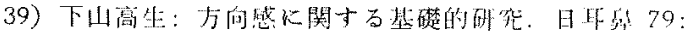
$459-477,1976$.

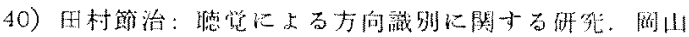
医学棑詰 66:425-429, 1954.

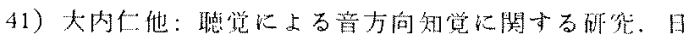

耳多 60:241-249, 1957 .

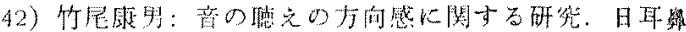
$67: 106-117,1964$.

43) Lawrence $M$ : Middle ear muscle influence on binaural hearing. Arch Otolaryng. 82: 478-482, 1965.

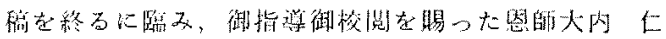

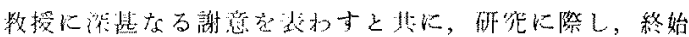

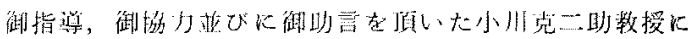

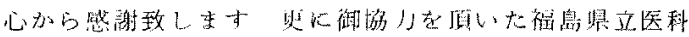

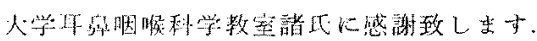

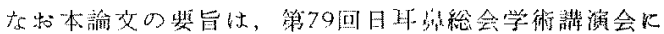
括いて器望した。

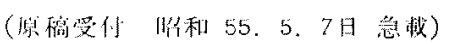

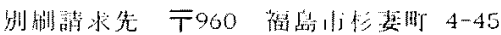

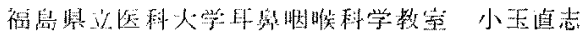

